\title{
Do All Black Lives Matter Equally to Black People? Respectability Politics and the Limitations of Linked Fate
}

\author{
Tehama Lopez Bunyasi \\ George Mason University \\ Candis Watts Smith \\ University of North Carolina-Chapel Hill
}

\begin{abstract}
Cathy Cohen's (1999) theory of secondary marginalization helps to explain why the needs of some members of Black communities are not prioritized on "the" Black political agenda; indeed, some groups are ignored altogether as mainstream Black public opinion shifts to the right (Tate 2010). However, the contemporary movement for Black Lives calls for an intersectional approach to Black politics. Its platform requires participants to take seriously the notion that since Black communities are diverse, so are the needs of its members. To what extent are Blacks likely to believe that those who face secondary marginalization should be prioritized on the Black political agenda? What is the role of linked fate in galvanizing support around these marginalized Blacks? To what extent does respectability politics serve to hinder a broader embrace of Blacks who face different sets of interlocking systems of oppression, such as Black women, formerly incarcerated Blacks, undocumented Black people, and Black members of LBGTQ communities in an era marked by Black social movements? We analyze data from the 2016 Collaborative Multi-Racial PostElection Survey (CMPS) to assess whether all Black lives matter to Black Americans.
\end{abstract}

Keywords: Black Lives Matter, respectability politics, linked fate, secondary marginalization, group consciousness, LGBT, intersectionality

Address correspondence and reprint requests to: Candis Watts Smith, University of North Carolina-Chapel Hill, Abernethy Hall, 131 S. Columbia St., CB\#3435, Chapel Hill, NC 27599. E-mail: cwsmith@unc.edu 
Scholars of American political behavior have long recognized and made efforts to explain Black political homogeneity, illustrated by this group's relatively unified support of Democratic political candidates despite increasing socioeconomic heterogeneity (Dawson 1994; Haynie and Watts 2010). Racial solidarity and racial group consciousness have provided helpful explanations to this empirical quandary (Allen, Dawson and Brown 1989; Olsen 1970; Shingles 1981; Verba and Nie 1972). Relatedly, Dawson's (1994) Black utility heuristic theory predicts that as long as Blacks perceive that their individual life chances are inextricably linked to other group members, they are likely to incorporate their racial group's well-being into their political decision making calculus (Dawson 1994).

However, scholars have also noted the political divisions and ideological diversity that exists among this group (Dawson 2001). While there are a number of prominent examples of political divisiveness over the course of Black American history, the recent rise and development of the Black Lives Matter (BLM) Movement and the Movement for Black Lives $(\mathrm{M} 4 \mathrm{BL})^{1}$ have served to highlight several important, persistent points of division in mainstream 21 st century Black politics. BLM and M4BL, like previous Black social movements, hinge on a "determination to preserve black life in the face of white supremacist violence," which "has always been a radical principle" (Rickford 2016). Martin Luther King Jr. noted that the Black social movement forces "America to face all its interrelated flaws - racism, poverty, militarism, and materialism. It is exposing the evils that are rooted deeply in the whole structure of our society. It reveals systemic rather than superficial flaws and suggests that radical reconstruction of society itself is the real issue to be faced" (King 1969). Today's Black social movement falls into that tradition.

This contemporary social movement also exposes fissures that are deeply embedded in traditional, mainstream Black politics. Scholars have noted that as the politics of respectability has evolved to accommodate neoliberalism, racial inequality has been "reproduced within, and not simply on black communities," thus exacerbating the effects of secondary marginalization (Harris 2014; Spence 2012). Cathy Cohen's (1999) theory of secondary marginalization highlights the notion that the needs of some members of Black communities are not prioritized on "the" Black political agenda; indeed, some groups are ignored altogether as mainstream Black public opinion shifts to the right (Tate 2010). However, the contemporary M4BL, which was started by queer, Black, Millennial women, is unapologetically Black, intersectional, and rejects respectability politics. 
Two years after BLM came to prominence, researchers found that while four-in-10 Americans supported the movement, nearly 65\% of Black Americans threw their support behind the movement (Horowitz and Livingston 2016). Given the attention of the movement in the media as well as the high levels of support among Black people, we should like to know whether intersectional politics is being reflected in the contemporary political attitudes and opinions of average Black citizens. That is, to what extent are Blacks likely to believe that those who have traditionally faced secondary marginalization be prioritized on the Black political agenda? What is the role of linked fate in galvanizing support around the most marginalized Blacks? To what extent do respectability politics serve to hinder a broader embrace of Blacks who face different sets of interlocking systems of oppression, such as Black women, justice-involved Blacks, undocumented Black immigrants, and Black LBGTQ community members in an era marked by Black social movements? Does a tendency to explain racial disparities in terms of either individual failings or structural biases differently shape the prioritization of Black sub-groups?

We analyze data from the 2016 Collaborative Multi-Racial Post-Election Survey (CMPS), which includes a sample of over 3,000 Blacks to answer these questions. We assess whether the contemporary Black social movement's call for careful consideration of queer, transgender, justice-involved, female, and undocumented immigrant Blacks has been mainstreamed. A mainstreamed intersectional politics would be marked by an overwhelming affirmation to support the particular challenges posed to groups that have traditionally been excluded from the Black political "consensus" agenda.

This is an important line of inquiry given the ongoing debate concerning a social movement that calls attention to the fact that Black lives are devalued in the United States. While most Blacks tend to agree on the premise of the movement, there is a great deal of contention around how to attend to these challenges. This study adds to the literature by simultaneously and quantitatively accounting for the factors that bring Blacks together as well as those that are likely to cause fissures among them. We begin by outlining the major concepts that must be put into conversation with one another to better understand contemporary Black politics: linked fate, respectability politics, and secondary marginalization, and then briefly comment on what makes this moment in Black politics susceptible to developing a more inclusive, intersectional Black political agenda. Thereafter, we explain how we operationalize these central concepts, prior to presenting the results of our analysis. 
To summarize, we find that though linked fate enhances the likelihood that Blacks embrace marginalized group members, there are limits. Though linked fate provides broad-brush support to uplift the racial group, it does not necessarily seep in to cover the most vulnerable Black Americans. Our results reveal that respectability politics leads Black people to disengage from supporting Blacks who have been marginalized. Specifically, we find that relying on individualist rather than structural explanations of racial inequality, believing that Blacks ought to place a high value on a "traditional" Black family structure, and acquiescence to practices of racial profiling in the name of law and order serve as countervailing forces to linked fate. Taken together, we find that even in the BLM era, those who are already doubly or triply subjected in American society may still have difficulty in experiencing relief in their own communities.

\section{A POLITICIZED RACIAL IDENTITY}

While one's group identity denotes the extent to which one is aware of and attached to a particular racial group, group consciousness is best understood as "representing a more developed stage of identification, a deepening of group attachments to include a belief that one's life chances are inextricably tied to the group" (Gay, Hochschild and White 2016). Individuals belong to many different kinds of groups, but we tend to see that those identities that have political relevance (e.g. race, ethnicity, gender) are more likely to trigger a sense of group consciousness. Gay, Hochschild and White explain, "feeling bound by membership and not simply 'close' to members, in sum, is an important antecedent to cooperation and giving priority to group objectives" (Gay, Hochschild and White 2016). Paula McClain et al. explain that racial group consciousness is "in-group identification politicized by a set of ideological beliefs about one's group's social standing as well as a view that collective action is the best means by which the group can improve its status and realize its interests"; they suggest that linked fate is a parsimonious and accurate measure of group consciousness (McClain et al. 2009). Additionally, Sanchez and Vargas (2016) find that few methodological issues arise when employing the measure of linked fate to assess a politicized group identity among Black Americans.

There is a great deal of evidence that reveals the influence of linked fate on Blacks in the U.S. Scholars like Michael Dawson have shown that unlike Whites who are more likely to become Republicans as they 
ascend the socioeconomic ladder, Blacks, on average, tend to maintain support of the political party that is most likely to help (or least likely to do irreparable damage to) members of their racial group, even as their own individual socioeconomic status improves (Allen, Dawson and Brown 1989; Dawson 1994, 2001). While there has been a recent uptick in conservatism among affluent Blacks, the influence of linked fate has led to Blacks being more liberal than Whites on issues such as social welfare, affirmative action, and government spending. A theory of linked fate also helps us to understand that Blacks have historically been inclined to "support an activist welfare state as a form of racial redress" (Tate 2010).

While linked fate conceptually helps us to understand the relative homogeneity in prominent areas of political discourse (e.g. voting, partisan loyalties), there still exists a great deal of heterogeneity within the group. The theory and paradigm of intersectionality helps to illuminate not only the diversity of identities that Black people may hold-due to sexuality, gender, class, and immigration status - but also that the structural constraints and advantages linked to each identity overlap to influence individuals' life chances in different ways (Crenshaw 1991; Jordan-Zachery 2007). Linked fate helps us to understand Blacks' political behavior with a broad brush, but research shows that racial linked fate is a separate construct from other kinds of group consciousness, such as Black feminist consciousness, or a recognition of the special challenges that Black women face due to the paternalism and racism (Simien and Clawson 2004; Simien 2005). Though extant research shows that racial and race-gendered group consciousness tend to increase together, it behooves us to recognize that racial linked fate does not necessarily capture the sentiments that Blacks feel toward specific, marginalized groups. Or in other words, though linked fate is often viewed as a liberalizing force, it does not provide indiscriminate support for all types of Black people, perhaps especially those who are deemed as undeserving, deviant, or "bad" representatives of the group. Needless to say, Black politics is complicated by conservative practices of respectability politics and, consequently, secondary marginalization.

\section{SECONDARY MARGINALIZATION AND THE EVOLUTION OF RESPECTABILITY POLITICS}

Evelyn Brooks Higginbotham (1993) coined the term "politics of respectability." She explains that late 19th century, Black, middle-class, Baptist 
women imbibed an ideology of respectability politics in effort to resist and even dissolve White Americans' negative stereotypes about Black women. This resistance manifested through a specific standard of personal comportment and practicing of particular behaviors, including proper dress, thrift, cleanliness of property, temperance, polite manners and language, and sexual purity (Higginbotham 1993). The assumption behind the philosophy of respectability politics is that if Blacks assimilate and behave more like Whites, equal treatment will follow. Higginbotham explains, "Black leaders argued that 'proper' and 'respectable' behavior proved blacks worthy of equal civil and political rights. Conversely, nonconformity was equated with deviance and pathology and was often cited as a cause of racial inequality and injustice" (Higginbotham 1992).

The politics of respectability has long been an important and debated aspect of Black politics. Some argue that respectability politics has been a useful tactic in successful Black social movements (Kennedy 2015; Reynolds 2015). Proponents view respectability politics as a way to persuade Whites that Blacks are deserving of the rights promised to them by the U.S. Constitution. Randall Kennedy (2015) adds to this defense of respectability politics noting that this way of thinking is necessary to "improve our [Blacks'] chances of surviving and thriving" in a society marked by racism. Kennedy recognizes that there have been "misapplications of respectability," such as evaluating the character or the allegedly troubled background of those individuals who are targeted by the police and either subjected to excessive force and/or extrajudicial violence; but he argues that these misapplications "should not obscure an essential fact: any marginalized group should be attentive to how it is perceived" (Kennedy 2015).

Political scientist Fredrick Harris reiterates that respectability politics started as a philosophy rooted in linked fate by Black elites to "uplift the race," but asserts that the ideology "has now evolved into one of the hallmarks of black politics," and is currently a governing philosophy that "centers on managing the behavior of black people left behind in a society touted as being full of opportunity"; the philosophy has morphed from "lift as we climb" (a collective endeavor) to "lift up thyself" (centering the behavior and attitudes of the individual) (Harris 2014). Though there are threads of the original version of respectability politics that run through today's incarnation, the modern form is inextricably linked to neoliberalism, or a "governing agenda that includes the privatization of government programs and institutions," and "involves an intensifying rhetoric that is grounded in the belief that markets, in and 
of themselves, are better able than governments to produce, in particular, economic outcomes that are fair, sensible, and good for all" (Cohen 2010; Spence 2011; Taylor 2016). Legal scholar Osagie Obasogie and Zachary Newman succinctly describe the contemporary version of Black respectability politics this way (Obasogie and Newman 2016, 543):

[T] he notion that minorities can best respond to structural racism by individually behaving in a "respectable" manner that elicits the esteem of Whites as a way to insulate the self from attack while also promoting a positive group image that can "uplift" the reputation of the group.

This contemporary version of respectability politics relies on policing individual behavior and attitudes rather than directly addressing structural forces that perpetuate racial inequalities (Aziz 2015; Harris 2014). This accommodates neoliberalism because "the virtues of self-care and selfcorrection are framed as strategies to lift the poor people out of their condition by preparing them for the market economy" (Harris 2014).

Cohen (1999; 2010) reveals that Black political elites as well as middleclass Blacks are especially likely to rely on notions of individuality and good behavior when dealing with young and poor Black people rather than focus on dismantling the systemic inequalities they face, such as unequal access to quality education or gainful employment. The effects of a governing philosophy dictated by neoliberalism are exacerbated by respectability politics. Both respectability and neoliberalism serve to dismiss the particular challenges faced by those who do not mimic dominant depictions of deservingness.

While perhaps a survival mechanism in the past, the logic of respectability politics, as it has evolved and plays out today, is one that some view as limiting efforts toward a more egalitarian, democratic society because it constrains Blacks to "hegemonic articulations of gender, class, and sexuality" (Higginbotham 1992). From this vantage point, "misapplications of respectability" have become a commonsense feature of America's racialized social system, and is now upheld by two pillars of the "normative moral super structure" that control access to resources and belonging in the United States (Cohen 2004), namely (1) assumptions of the nuclear family structure and (2) the license to surveil and search people whose location appears "out of place" and behavior appears "out of step" to the White, middle-class, heterosexist gaze.

For at least half a century, dominant political rhetoric has echoed the Moynihan Report's (1965) prescriptions for "the cycle of poverty and 
disadvantage" that beset African Americans relative to Whites: a stable, two-parent household. By overlooking present-day discrimination and the structural apparatuses that privilege White over Black Americans, this neo-conservative agenda pathologized female-led households for "operating on one principle, while the great majority of the population, and the one with the most advantages to begin with, is operating on another" (Moynihan 1965, 28). Since mid-1960s, Black Americans of various ideological stripes have publicly endorsed heteronormative marriage as a goal to uplift the community, with either tacit or intentional aims of projecting Black people as wholesome, chaste, and fiscally prudent as Whites (Cohen 2004; Dawson 2001).

By striving for and celebrating heterosexual marriage as a goal for the racial community, a significant proportion of African Americans become cast as undesirable and deprioritized members of the racial group: single parents ( particularly, single mothers, who either are or are not recipients of welfare), queer people (who may not aspire to heterosexual coupling), and justice-involved parents (who are not present in the home to raise their children). Through the politics of respectability, these members of Black communities are held in a state of exception when certain Black activists present their "best face" to gatekeepers of power and resources.

Relatedly, some Blacks endorse hegemonic goals of social order through their support for state surveillance of some people of color in order to maintain law and order. Black public discourse is in a state of conflict over the presentation of Black bodies in public space with some members in agreement that one's attire, the location of one's waistband, hairstyle, and general behavior can "reasonably" and "understandably" invite more intense scrutiny (Harris 2014). When people of color endorse racial profiling in exchange for victories in a war against drugs, terrorism, or undocumented immigration, they tacitly work to maintain the exclusion of many people of color (Waddington 1999).

Cathy Cohen (1999) describes the outcome of these exclusionary processes as secondary marginalization. Cohen explains that there are some issues that are framed as "consensus issues," or issues that are understood as "advancing the interests of the entire black community" and are "more likely to be 'owned' as community issues meriting group political mobilization" (Cohen 1999). These issues often are made highly visible and are prioritized on any Black political agenda. However, there are also issues that have an acute (negative) effect on smaller segments of the racial group, which she calls "cross-cutting" issues. If the smaller segment is one that is socially constructed as deviant, undeserving, immoral, or unworthy, it 
is likely that the challenges faced by that group will not receive the attention of Black political leaders, especially if those leaders have attained a modicum of respect from dominant society (Schneider and Ingram 1993). Consequently, Blacks "must weigh concern over the respectability and legitimization of black communities in the eyes of dominant groups against concern over the well-being of those most vulnerable in our communities, as they struggle against very public, stigmatizing issues" (Cohen 1999, 15). The further relegation and ostracism of stigmatized segments of an already oppressed group is the process of secondary marginalization.

The most damning implication of respectability politics is that it implies that not all lives matter, or at least suggests some lives matter more than others. The narratives of slain Black people are often accompanied by details of their past. Those who do not follow traditional, White-middle class, heterosexual patriarchal norms are (perhaps unintentionally) deemed as deviants, and thus, not as "grieveable" (Obasogie and Newman 2016, 555). Therefore, those who endorse a politics of respectability are disposed to focus on individuals who make more "compelling victims," not only so that (White) conservatives can be persuaded that state violence is real but also to persuade White and Black moderates of the same idea.

The contemporary M4BL not only rejects respectability as a tool of resistance in contrast to some previous iterations of Black social movements, but it also elucidates the ways in which respectability politics is often employed to maintain inequality, especially for those who face secondary marginalization. From this perspective, respectability politics is an idea whose time has passed.

\section{BLACK POLITICS IN THE NEW MILLENNIUM}

Cohen (2004) wrote that we ought to expect Black politics to evolve and should "take seriously the possibility that in the space created by deviant discourse and practice, especially in Black communities, a new radical politics of deviance could emerge"; this evolution is likely to happen when a greater number of people recognize that acquiescing to the politics of respectability will not uproot the foundations of a racialized social system. This prediction is prescient. Scholar-activist Keeanga-Yamahtta Taylor explains, "The killing of Mike Brown, along with an ever-growing list of other unarmed Black people, drove holes in the logic that Black people simply doing the 'right things'...could overcome the perennial 
crises within Black America" (Taylor 2016). In the wake of this realization, the BLM Movement and the M4BL turned a moment into a movement. This movement, like the Civil Rights Movement, works toward dismantling White supremacy, but is simultaneously in direct conflict with the "old guard" of Black politics because both center on an intersectional approach to Black politics and reject the requirement for respectability politics.

As a point of reference, ordained minister and author Barbara Reynolds (2015) illustrates the logic and rhetoric of respectability politics in a Washington Post article, where she asserts that most people who were activists in the 1960s "admire the cause and courage of these young activists but fundamentally disagree with their [Black Lives Matter's] approach"; she explains:

Trained in the tradition of Martin Luther King Jr., we were nonviolent activists who won hearts by conveying respectability and changed laws by delivering a message of love and unity... In the 1960s, activists confronted white mobs and police with dignity and decorum, sometimes dressing in church clothes and kneeling in prayer during protests to make a clear distinction between who was evil and who was good.

Reynolds focuses on particular behavior and personal comportment, including proper dress, as tools of resistance. What's more, she highlights the necessity of proving to White audiences that Blacks are good and deserving of respect, rights, and dignity. In striking contrast, members of leaderful organizations like the BLM find this kind of sentiment troubling, as there is an implicit message that you must prove yourself to be good in order to gain rights that are already promised to you as citizens and human beings (Houston 2015; Pugh 2017; Taylor 2016). BGD blog writer Aleo Pugh (2017) explains,

Within the organization, there is a clear rejection of respectability politics, particularly the false relationships forged between speech, ways of dress and police harassment. There is also a rejection of conservative "keep the peace" theologies that are eagerly projected onto the BLM movement. Respectability politics are also renounced in the organization's guiding principles, just some of them being: centralizing Black women; and affirming queer and trans folk. This is an outright refusal to adhere to the queerphobic, patriarchal and classist ethos of the Civil Rights Movement, both in leadership and values. 
This movement was founded by queer, Black, Millennial women, and its platform not only rejects the politics of respectability but it requires its participants to take seriously the notion that since Black communities are diverse (e.g. family structure, gender, sexuality, immigration status), so are the needs of its members; it centers an intersectional approach to Black politics. The platform of the unified M4BL declares:

We believe in elevating the experiences and leadership of the most marginalized Black people, including but not limited to those who are women, queer, trans, femmes, gender nonconforming, Muslim, formerly and currently incarcerated, cash poor and working class, disabled, undocumented, and immigrant...There can be no liberation for all Black people if we do not center and fight for those who have been marginalized (M4BL).

Nonetheless, it should also be noted that "old guard," revered Black organizations are also slowly embracing an intersectional politics and even seeing through "the critical lenses provided by the \#BlackLivesMatter movement" (NAACP 2015) on issues such as environmental racism and mass incarceration. This adds to the NAACP's and Urban League's relatively recent move to view and support LGBT rights as civil rights. Leaders within these organizations have come around to the notion that "The African-American community and the gay and lesbian community are not and have never been separate communities" (Hutson 2013). Furthermore, Rev. William Barber has relaunched a poor people's campaign (McClain 2017). This new movement represents a shift from Black political elites who over the past several decades focused on improving the well-being of poor Black people, but not without also chastising them for not buying their children "Hooked on Phonics," or for stealing "pound cake"; indeed, President Obama, himself, was a proponent for neoliberal governance strategies to uplift the lives of working class and low-income Black citizens (Dawson and Francis 2016; Price 2016).

Americans across the country learned more about BLM not only as a social movement and political intervention but also as an ideological approach that can be characterized as intersectional. While "old guard" organizations appear to be open to some these influences, it should be made clear that there are still internal divisions among Black political elites and the masses about the extent to which this new "radical," intersectional agenda should be embraced (Hutson 2013). Keeping in mind both the potential shift in Black politics as well as resistance to change, 
it remains to be evaluated whether the ideas of the new movement are represented in the sentiments of average Black citizens.

\section{THEORETICAL EXPECTATIONS}

When most people think about BLM and M4BL, they are likely to think first and foremost about policing and police brutality. However, the movement is actually concerned with broader conceptions of the way that Black people face state violence - from the police as well as in other domains of American life, such as housing, education, and the criminal justice system. While the BLM seeks to affirm the notion that "Black lives are systematically and intentionally targeted for demise," it is also cognizant of the fact that different kinds of Black people face varied permutations and combinations of systems of oppression (Black Lives Matter Network). It has been noted that the contemporary M4BL "ain't your grandfather's Civil Rights movement," in large part because BLM and M4BL rely on intersectional Black feminist ideology.

Given that most people have a broad, loose understanding of the motives of the contemporary Black movement, we expect there to be a large variation in the extent to which Blacks are likely to believe that the challenges of certain groups of Blacks should be addressed head on; or in other words, we do not expect an intersectional Black politics to be reflected among Black respondents. Consequently, we hypothesize the following:

$H_{1}$ : Black Americans will vary in their belief that it is very important to address the challenges of Black women, formerly incarcerated Black people, undocumented Black immigrants, Black people who identify as lesbian or gay, and transgender Blacks.

To be clear, we predict that there will be a hierarchy of perceived deservingness among Black respondents. It is likely that Blacks will prioritize Black women first followed by those who have been formerly incarcerated because both of these groups make up a fairly large proportion of the population. While Black women have borne the brunt of respectability politics (Harris-Perry 2011; Higginbotham 1992; 1993), generally speaking, one might expect that they are not explicitly deemed as deviants among most Black people. Rather, their marginalization is a result of being both Black and female in a racist and patriarchal society. 
Relatedly, although those who have been previously incarcerated have traditionally been marginalized, scholars (e.g. Alexander 2010; Lerman and Weaver 2014; Pager 2007), filmmakers (e.g. DuVernay 2016; McQuirter 2016), and social activists have made an effort to illuminate the vast inequalities of the prison industrial complex and the resulting mass incarceration of Black and Latinx people in the United States. With increased attention around the inequities born out of America's criminal justice system, Blacks may feel particularly sympathetic to this group.

Undocumented Black immigrants are likely to fall next. Approximately, 9\% of Blacks in the United States are foreign born (Anderson 2015). Though Greer (2013) notes that Black immigrants are at times viewed as (and aimed to be viewed) model minorities, and relatedly, Rogers (2006) reveals that many Black immigrants feel that they have an exit option in the face of persistent racism, Smith (2014) notes that we ought to expect a sense of diasporic consciousness to arise between native- and foreign-born Blacks. She defines this as "the (mental) tightrope that people of African descent who live in the United States walk as they try to balance their superordinate racial identity (and the political interests associated with it) with their subgroup or ethnic identity and its closely associated political interest" (Smith 2014). Taken together, we see how complex of a relationship native- and foreign-born Blacks have with one another, but typically in the face of anti-Black racism, we ought to expect a modicum of coalescence (Kim 2000). Native-born Black Americans tend to have fairly conservative attitudes about immigrationlargely due to a sense of economic threat (Capers and Smith 2015; Diamond 1998) - but seem to have open attitudes about immigrants themselves (Carter and Pérez 2016); generally speaking, Black Americans do not wish to participate in White supremacist notions of American belonging or identity (Carter and Pérez 2016; Diamond 1998; Masuoka and Junn 2013).

It is likely that lesbian and gay as well as transgender Blacks will fall at the bottom of the deservingness hierarchy, given historical attitudes about those who do not follow heterosexual and cisgender norms among Blacks (Cohen 2004). A plethora of scholars have noted that, generally speaking, the politics of Black LGBT matters are predominately treated with silence, as if Black gay and lesbian people do not exist (Griffin 2000), or through the lens of homophobia, which scholars suggest is rooted in both/either Black nationalism and/or so-called theologically driven homophobia (Ward 2005). Black nationalism is one of the most well-received Black ideologies among African Americans (Price 2009), and Black Americans 
are the most religious racial group in the country (Pew Research Center 2014). Though the United States has seen increasing openness to LGBT communities, the backlash against a left-leaning, liberal shift in some national Black organizations' orientation stances toward lesbian and gay people and their civil rights (e.g. gay marriage) was swift, negative, and public (Cohen 1999; Hutson 2013; Stanford 2013).

What are the major mechanisms leading to support or lack thereof for these groups? We believe there are several inter-related factors to consider. First, we consider linked fate. Linked fate remains a highly supported notion among Black Americans. Blacks are likely to believe that what happens to other Black people will have something to do with what happens to them. As such, those with higher levels of linked fate should be more likely to support various sub-groups of Blacks than those who report lower levels of linked fate. However, linked fate has its limits, and thus we view respectability politics, especially in its current iteration, as linked fate's primary countervailing force. Consequently, we predict that those who subscribe to respectability politics will be less likely to focus on the needs of groups that are not seen as respectable. Put simply,

$\mathrm{H}_{2}$ : Linked fate will increase the extent to which Blacks believe it very important to address the challenges of Black women, formerly incarcerated Black people, undocumented Black immigrants, Black people who identify as lesbian or gay, and transgender Blacks.

$H_{3}$ : Those who subscribe to respectability politics will be more likely to believe that it is not very important to address the challenges of Black women, formerly incarcerated Black people, undocumented Black immigrants, Black people who identify as lesbian or gay, and transgender Blacks.

\section{DATA, METHODS, AND MEASURES}

We rely on the Collaborative Multiracial Post-Election Survey (CMPS) 2016 (Barreto et al. 2017) to test our hypotheses. The responses were collected online in a respondent self-administered format between December 3, 2016 and February 15, 2017. The full sample includes a total of 10,145 individuals from major pan-ethnic and racial groups, including Whites, Blacks, Latinos, and Asians. The survey and invitation were available to respondents in English, Spanish, simplified and traditional Chinese, Korean, and Vietnamese. The data include registered and non-registered voters as well as non-citizens. The full data are weighted within the four 
ethno-racial groups to match the adult population in the 2015 ACS l-year data file for age, gender, education, nativity, ancestry, and voter registration status; all models presented here are weighted to reflect the demographics of Blacks in the United States, but descriptive statistics are presented in their raw form. We restrict our analysis to the 3,102 respondents who identified as Black or African American.

The primary outcome variables of interest measure the extent to which Blacks are willing to support the challenges posed to groups that have traditionally faced secondary marginalization in Black politics. We analyze the responses of Blacks to the following question: "How important is it for Blacks to address the challenges of the following groups": Black women; formerly incarcerated Black people; Black undocumented immigrants; Black gays and lesbians; and Black transgender people. Respondents were asked to select "not important at all," "somewhat important," or "very important" in response to each group. Given the structure of the provided responses, the multivariate analyses rely on ordinal logistic regressions.

We focus on two explanatory variables: linked fate and respectability politics. We rely on the two standard linked fate questions. First respondents are asked, "Do you think what happens generally to Black people in this country will have something to do with what happens in your life?" Then, for those who answer "yes," they are asked, "Will it affect you a lot, some, or not very much?"; linked fate is, therefore, operationalized as an ordinal variable.

Though there has yet to be a broader conversation about the affective components of linked fate (Price 2016), we created a new question to assess this: "Some people feel positively about the link they have with their racial or ethnic group members, while others feel negatively about the idea that their lives may be influenced by how well the larger groups is doing. Which comes closer to your feelings?" Response options included a positive, negative, or neutral answer; we use a dichotomous variable measuring those who answered "positively" versus those who did not.

The variables that comprise our construct of respectability evoke the two aforementioned pillars of the "normative moral superstructure": adherence to a "traditional" family structure and legitimacy of racial surveillance. ${ }^{2}$ Our measure of respectability politics concerning family structure is based on the question, "Of the following statements, which do you agree with more? 'Blacks should focus on making sure families have two parents' or 'Blacks should focus on making sure all families are supported no matter their make-up'." The variable is binary with 'two parents' set as equal to ' 1 '. To measure acquiescence for greater police surveillance and 
social control, respondents were asked to rate their level of agreement with the following statement in a four-item Likert scale from 'strongly agree' to 'strongly disagree': "Racial profiling is sometimes necessary as a law enforcement tool. ('Racial profiling' refers to targeting individuals from certain groups in the belief that they are more likely to commit crimes.)" In the models, this variable retained its ordinal character.

In addition to these central variables, we also take into consideration several control variables. Considering that contemporary respectability politics are informed by the notion that "minorities can best respond to structural racism by individually behaving" in a way that elicits respect from Whites (Obasogie and Newman 2016, 543), we leveraged questions provided by the CMPS to account for racial premises of neoliberal logic. Respondents were prompted, "Of the following factors please indicate whether or not each one is important or unimportant in explaining blackwhite disparities." They were then provided with several explanations, which they could provide their level of support, ranging from "very important" (1) to "not important at all" (4). The respondents were asked the extent to which they believed the following four factors influence Black-White disparities: "racial discrimination against Blacks"; "lower quality of schools in Black communities"; "lack of effort by Blacks"; and "family instability in the Black community."

Following scholars like Kluegel (1990), we combined responses to "discrimination" and "lower quality of schools" to produce a measure of structural explanations of racial inequality, and combined "lack of effort" and "family instability" to create a measure of individualist explanations of inequality. Finally, we subtracted the responses for structural views from individualist views to create a scale that allows us to ascertain the extent to which respondents rely on structural or individualist attributions of racial disparities (with higher values representing individualist attributions). We employ responses to these four questions in this way because they mimic the broad underlying assumptions of a respectability politics that has evolved to accommodate a neoliberal governance, which are "based on a fundamentally American sense of capitalism, individuality, and work ethic - that if you work hard, play by the rules and are a good law-abiding citizens of any race, nothing will obstruct you in your pursuit of a 'better life' and integration into social and economic prosperity" (Obasogie and Newman 2016, 549; Spence 2012).

Additionally, it has been noted, "Most frequently, preaching respectability reflects a class and generational fear, by black people who feel they have 
escaped the face of poor disenfranchised blacks, and entered respectable society" (Ioffe 2014). As such, we control for a number of demographics such as gender, income, education, and age. Household income and education are ordinal variables. Gender is coded so that female is the baseline group of comparison, and age is continuous.

We also capture variables that often influence Blacks' decision-making calculus-partisanship and ideology-as well as demographic variables such as gender, household income, and education. Given that the majority of Black Americans identify as Democrats, we created a model that would show the predictive value of being Republican or, separately, being a declared Independent or member of a third party, relative to those who identify as Democrat. A dichotomous variable for being Liberal is utilized to measure the effect of ideology, following Hajnal and Lee (2011). ${ }^{3}$

Moreover, we are cognizant that one's membership in various groups likely determines how one feels about that group (Tajfel and Turner 1986). Relatedly, research shows that having sustained interactions with lesbian and gay individuals liberalize individuals' attitudes toward members of this group (Sevecke et al. 2015). Consequently, we control for respondents' group membership or close relationship to members of marginalized groups. For example, in the model that assesses whether Blacks believe the challenges of formerly incarcerated Black people are important, we control for whether the respondent has been to jail or prison and/or knows a formerly incarcerated person. We control for whether one or more of the respondent's parents were born in the United States for the model relating Black undocumented immigrants; and we include a measure of whether the respondent identifies as lesbian, gay, or transgender and a separate measure for whether the respondent knows someone from the LGBTQ community for corresponding models. The question wording of independent variables and distribution of responses among Black respondents is provided in the appendix.

\section{RESULTS}

\section{Descriptive Results}

First, we assess the extent to which Blacks are willing to address the challenges posed by several marginalized Black groups. Figure 1 depicts the distribution of Black respondents' reported attitudes. This preliminary 


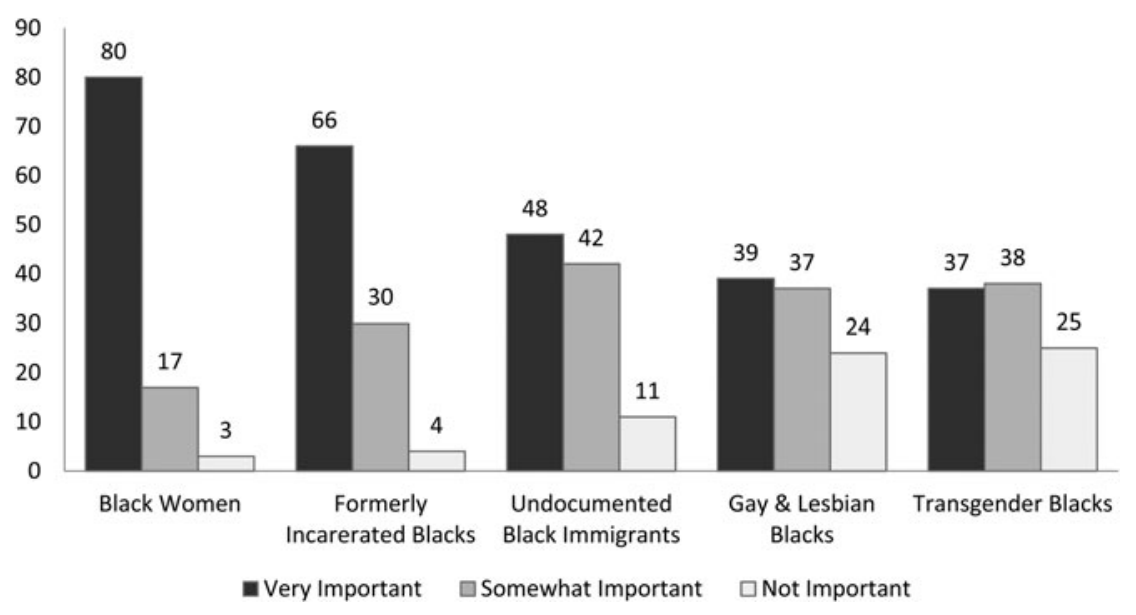

Figure 1. Level of Support for Addressing Challenges of Marginalized Groups.

data provide support for our first hypothesis. First, it should be noted that there is a great deal of support for Black women, as hypothesized; $80 \%$ of respondents believe that it is very important to take consideration of Black women. Following Black women, Blacks throw their support behind formerly incarcerated Blacks (66\% believe it is "very important" to consider this group's challenges) and Black undocumented immigrants (48\% of Blacks believe this group should be fully supported). As predicted, the levels of full support for addressing the challenges of gay and lesbian Blacks as well as for transgender Blacks lags significantly behind other groups (39\% and $37 \%$, respectively, think it is very important to address their challenges).

There are multiple ways to interpret these initial findings. One way is to focus on those who suggest that it is "not important at all" to address these groups. From this perspective, there is evidence that intersectional politics has the potential to thrive among Black Americans. Relatedly, close to $30 \%$ of Black respondents believe that all five of these groups' issues are "very important." On the other hand, it should be noted that nearly one in four Blacks believe that the needs of Black lesbian, gay, and transgender individuals are not important at all. Members of these groups have historically been marginalized and still continue to be, according to our analysis. Overall, there is a great deal of variation across and within the groups. Our next set of analyses test our hypotheses that aim to explain these differences in levels of support. 


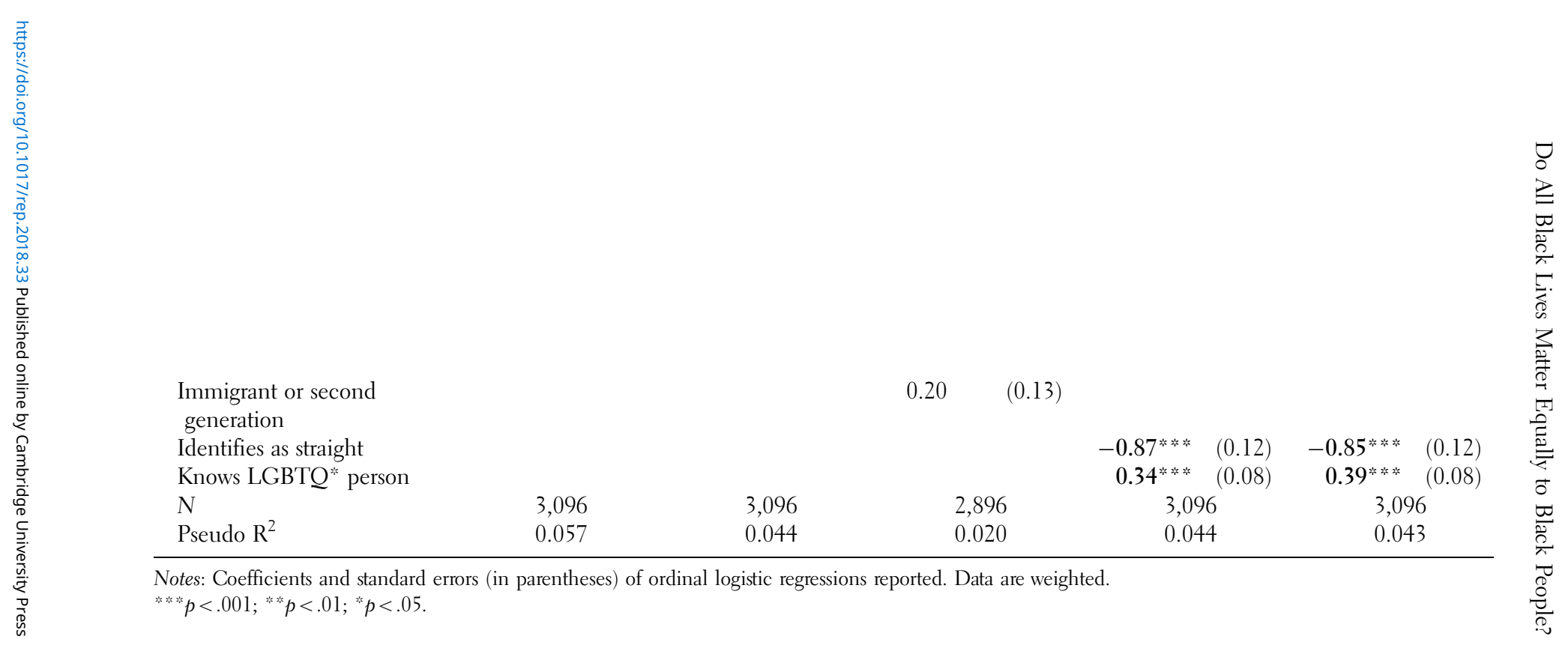

Immigrant or second

$* * * * 0.001 ; * * p<.01 ; * p<.05$ 


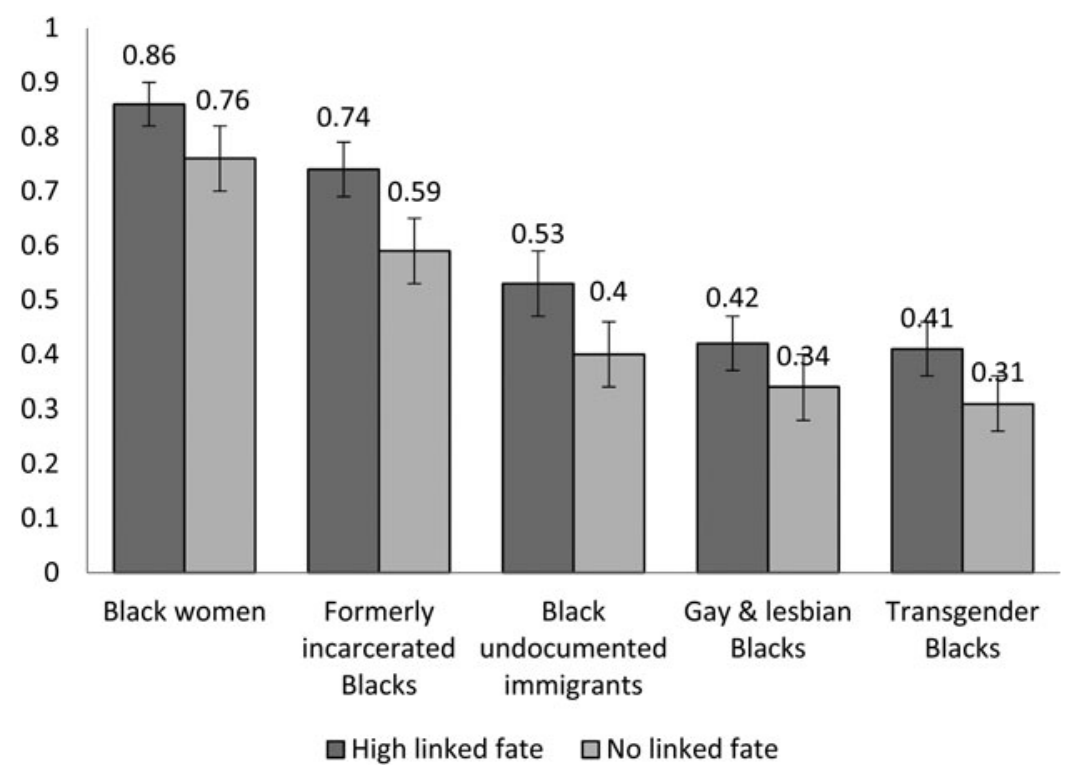

Figure 2. Predicted Probability of High Support for Marginalized Groups Given Linked Fate.

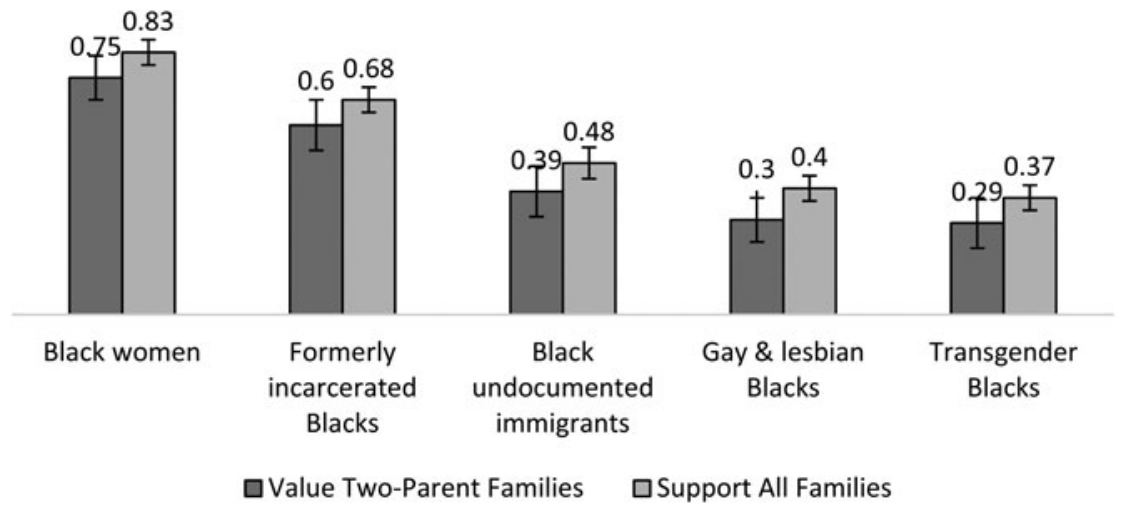

Figure 3. Predicted Probability of High Support for Marginalized Groups Given Family Prioritization.

\section{Multivariate Analyses}

The remainder of our hypotheses is tested with a series of ordinal logistic regressions, reported in Table 1 . Considering the fact that it is difficult to 


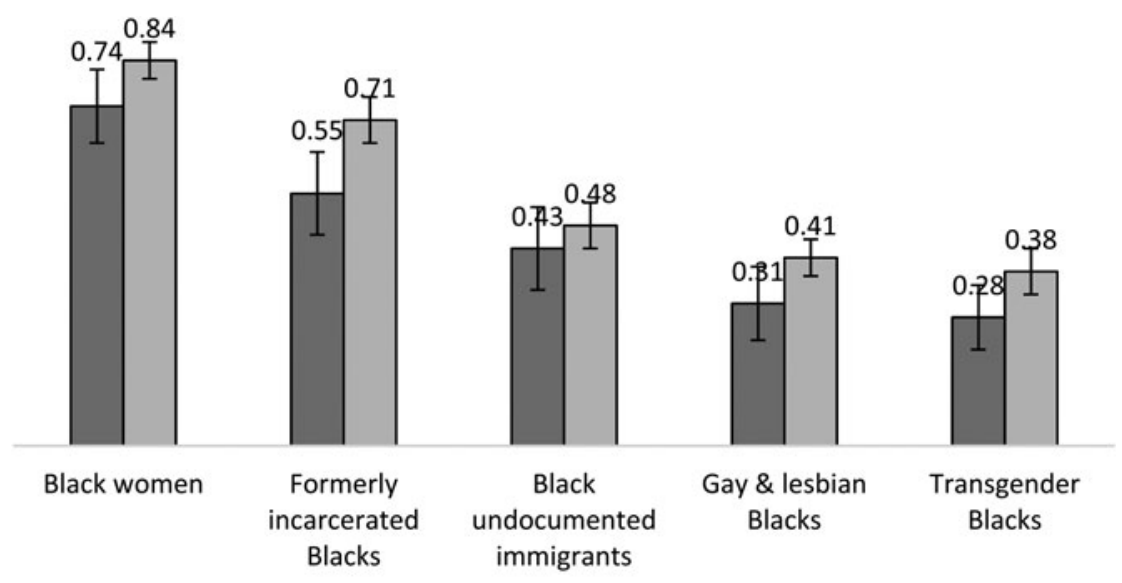

$\square$ Strong support for law and order $\quad \square$ Weak support for law and order

Figure 4. Predicted Probability of High Support for Marginalized Groups Given Adherence to Norms of Law and Order.

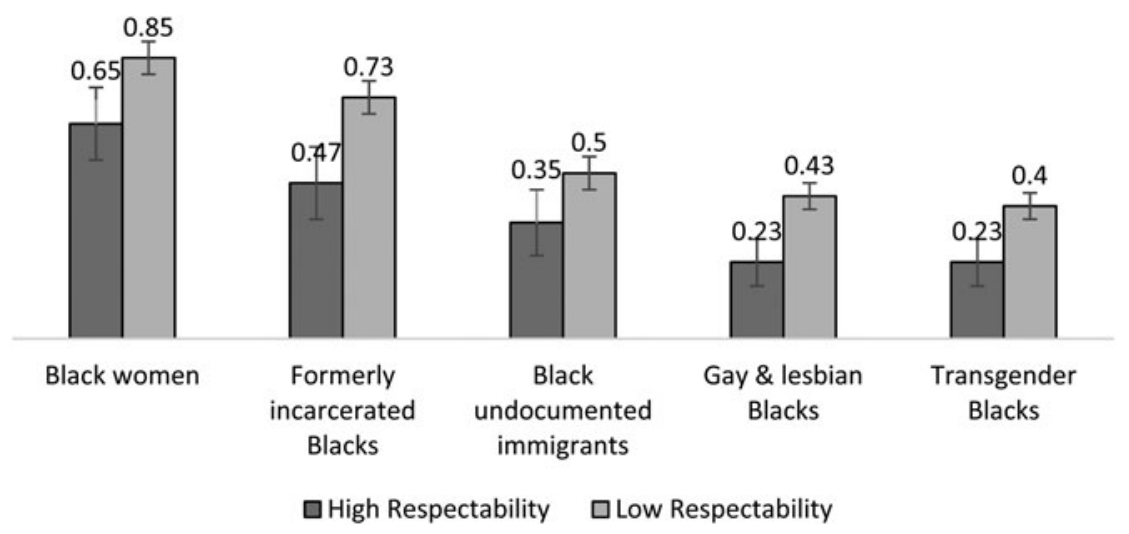

Figure 5. Predicted Probability of High Support for Marginalized Groups. Given Endorsement of Respectability Politics (i.e. Combined Support of Two Parents Families and Law \& Order).

interpret ordinal logistic regression coefficients, we provide illustrations of the predicted probabilities of believing that Blacks of various groups' challenges should be central to Black politics in Figures 2-5.

Overall, we find support for remaining hypotheses; each of the independent variables of concern are statistically significant even after 
controlling for explanations for Black-White disparities and traditionally important demographic and political orientation variables. We begin our detailed discussion with the first set of columns in Table 1, which outlines the determinants of levels of support for Black women. As a sense of linked fate increases, we find that the likelihood that Blacks who believe that Black women's challenges are very important to consider on a Black political agenda increases by 10 percentage points from $76 \%$ for those whose report no sense of linked fate to $86 \%$ for those who believe that what happens to other Blacks will affect their own lives a lot (Figure 2). The affective component of linked fate, however, makes no statistically significant difference in the way that Blacks prioritize addressing the challenges of Black women.

Additionally, as predicted, endorsement of two-parent households (Figure 3) and of racial profiling (Figure 4) is related to a de-prioritization of issues affecting Black women. Black respondents who believe Blacks should focus on supporting families with two parents and endorse racial profiling as a necessary tool of law enforcement has a 65\% chance of supporting Black women, whereas Blacks who dispel these racist-heterosexist norms have an $85 \%$ likelihood of supporting Black women (Figure 5). ${ }^{4}$ The combination of measures of respectability serve to severely dampen the extent to which some Blacks are willing to take on the ravages of paternalism and sexism. What's more, we find that orientations that prioritize individualist attributions of inequality more so than structural attributions serves to diminish support for Black women; indeed, this is the only model in which individualist attributions predict support for a marginalized group. Those who primarily rely on structural attributions of inequality are $87 \%$ likely to suggest that Black women's issues are very important; this decreases to $74 \%$ among those who primarily rely on individual attributions.

Our results also reveal that younger Blacks are less likely to provide higher levels of support for Black women than their predecessors. Although we do not test this thesis here it is possible that older Black American women-including those in the Black Boomer and GenXfind their gender identity to be a more salient component of their everyday experiences having lived through the Women's Movement and the Combahee River Collective, or in the immediate wake of them, and may see the advancement of equal rights more prominently through a lens of gender. This finding also underscores a study of Black women at the Women's March, which revealed that Black Boomers were overrepresented among Black women at the country's largest day of demonstration Lopez Bunyasi and Smith (2018). 
We find that many of the predictors of Blacks' attitudes toward Black women are mirrored in the analysis for formerly incarcerated individuals. Linked fate increases support for this group by 14 percentage points (59$74 \%$ ), and feeling positive about one's connection to other Blacks increases support for this marginalized group by five percentage points. Components of respectability politics provides a great deal of explanatory power. Those who value a two-parent family structure are eight points less likely to support justice-involved Blacks (see Figure 3), while the jump across the range of sentiments toward "law and order" is 16 percentage points (see Figure 4). Additionally, Blacks who simultaneously take conservative postures around family structure and racial profiling have a $47 \%$ likelihood of emphasizing the issues of their justice-involved racial peers, while disavowing these norms increases the probability of centering the lives of this group by 26 percentage points (Figure 5).

Our hypotheses are again supported in column 3 of Table 1, which shows that linked fate influences Black respondents' sentiments toward undocumented Black immigrants in the expected direction; the chances of suggesting that undocumented Black immigrants' issues are very important jumps from $40 \%$ among those who report low levels (or those who responded that they have no sense linked fate) of linked fate to $53 \%$ of those with high levels of linked fate. A positive feeling about this link results in a six-percentage point difference from those who feel either negatively or neutrally about their connection to other Blacks. Meanwhile, endorsement of the nuclear family and racial profiling are related to a de-prioritization of Black undocumented immigrants; together, they reduce the support of Black undocumented immigrants to 35\%, 15 percentage points below those Blacks who reject these racist and heterosexist norms (Figure 5).

While youth was associated with lower levels of support for Black women than older Blacks, the opposite is true here. Younger Black Americans may be taking a cue from the BLM. For instance, after the Supreme Court made a decision on President Obama's Deferred Action for Childhood Arrivals (DACA), the BML network immediately asserted that they would join the fight against deportations, thus making the issue salient among young people (Rivas 2016). Unfortunately, we are unable to compare Blacks' sentiments about undocumented and authorized Black immigrants - two groups that may be looked upon differently due to their legal status in the United States.

Finally, we turn to Blacks' attitudes toward LGBT community members. Previously, we noted that levels of support were lowest for gay 
and lesbian Blacks as well as for transgender Black people, but we find that these levels of support are bolstered by a sense of linked fate. Figure 2 shows an 8-10 percentage-point increase between those who have no linked fate and those who have high levels of linked fate in the probability of believing that Blacks should prioritize the needs of these groups. Blacks who feel positive about their connection to other Black people increase their support by 4-5 percentage points.

When Blacks believe that it is more important to support two-parent households and when they are willing to support racial profiling, Blacks' likelihood of secondarily marginalizing gay, lesbian, and trans members of their own racial group increases by about 20 percentage points in comparison to their peers who take a stand against the privileging of nuclear families and oppose race-targeted policing (Figure 5).

In addition to the independent variables, there are a number of control variables that are worth discussing. First, younger Blacks provide slightly higher levels of support than older Blacks for members of LGBT communities than older Blacks. Also, identifying as politically liberal consistently influences Blacks to be more open to supporting groups that have historically faced secondary marginalization. Democrats are more likely than Republicans or Blacks who do not identify with either of the two major political parties to support marginalized Blacks, but our results show that partisanship has a less consistent effect than political ideological on these matters. Recently, scholars have begun to highlight the fact that Blacks' partisanship does not neatly map onto the traditional conservative-liberal spectrum (Hajnal and Lee 2011; Philpot 2017). As such, conservatism is likely to be associated with social and cultural matters rather than economic ones, which is why we see that Blacks' ideological leaning as liberal has such consistent predictive powers. ${ }^{5}$

Finally, our results generally reveal that having a personal connection with or being a member of a marginalized segment of the Black population influences one's attitudes about the group. Being a formerly incarcerated person and/or knowing someone who is increases the chances of supporting the notion that it is very important to address the special challenges of this group. It should be noted that $70 \%$ of respondents either identified themselves as formerly incarcerated or said that they knew someone who served time in jail or prison, which is to be expected given the trends of mass incarceration in the United States. Meanwhile, the analysis shows that those who identify as heterosexual are less supportive of LGBTQ community members; however, this effect is countered when one knows someone who identifies as lesbian, gay, or transgender. 


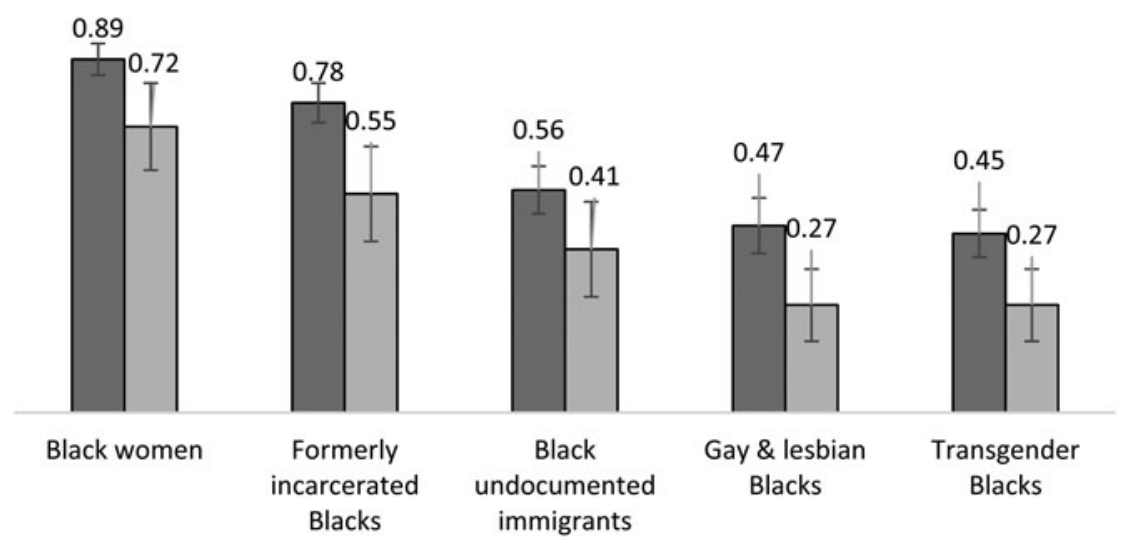

$\square$ High linked fate \& Low Respectability $\square$ High linked fate \& High Respectability

Figure 6. Predicted Probability of High Support for Marginalized Groups given. High Linked Fate and Varying Endorsement of Respectability Politics.

In general, our control variables are in line with the existing literature, thereby providing greater confidence in the results.

\section{The Effects of Being Woke}

While we have examined these attitudes-linked fate and respectability politics - separately, it would be remiss of us to not consider the additive effects of the sentiments we have analyzed thus far. Figure 6 illustrates the relationship between linked fate and respectability politics on Blacks' attitudes toward prioritizing traditionally marginalized groups. Because high levels of linked fate are common among Black Americans, we manipulate the extent to which people adhere to respectability politics. In each instance, we find that those who report both (a) feeling that what happens to Black people in this country will have "a lot" to do with what happens in their life, and (b) weak support for respectability politics (those who agree that all families should be supported and do not endorse racial profiling) range between 15 (undocumented Black immigrants) to 23 (formerly incarcerated Black) percentage points higher in their support for marginalized sub-groups than those with both high levels of linked fate and high levels of respectability. ${ }^{6}$

However, even among those who might be considered the "wokest" Black respondents - those with high group consciousness and low levels 
of respectability - there is a wide range of support for Blacks across these groups. LGBT Blacks still do not have the full support of half of the most open members of their group. "Woke" Blacks have a $47 \%$ probability of believing it is very important to support the challenges Black lesbian and gay people face, and they have only a $45 \%$ likelihood of fully supporting transgender Blacks in contrast to Black women and justice-involved Blacks, who maintain overwhelming support from this group. People who seem most critical of a matrix of domination and who might be seen as most inclusive of all Black people still prioritize sub-groups of Black people in a hierarchical fashion.

Conversely, we might think of those with high levels of linked fate and an orientation toward respectability politics as mimicking the sentiments of the "old guard" of Black politics. This group of Black respondents voice their overwhelming support for Black women (with a $72 \%$ probability of agreeing that Black women's issues should be prioritized), but leave nearly all the other groups behind. The likelihood of giving strong support to justice-involved Blacks is just over half (55\%) for high linked fate-high respectability Blacks, and their prioritization other groups garner even less. Overall, these results more clearly illuminate that linked fate is not a stopgap mechanism against secondary marginalization.

\section{DISCUSSION AND CONCLUSION}

There have long existed intersectional, feminist political ideologies among Blacks in the United States (Crenshaw 1991; Dawson 2001; Jordan-Zachery 2007; Smooth 2006; Taylor 2017), but historically, the most prominent social movements have been ones that were hierarchical, privileging men as the face of activist leadership and foot soldierdom, and relegating women to the background or worse. ${ }^{7}$ Respectability politics were also a key ingredient of the Civil Rights Movement (Carbado and Weise 2004; Kennedy 2015; Reynolds 2015). In comparison to some social movements of the recent past, the contemporary M4BL challenges the assumptions underlying the politics of respectability; it perceives this philosophy as repressive to the secondarily marginalized segments of the Black community (Black women, undocumented Blacks, LBGT Blacks, formerly incarcerated Blacks, and the like), and inadvertently contributive to the White racial dominance that disadvantages Blacks relative to their similarly situated White counterparts. 
Despite ostensible indications that the contemporary M4BL enjoys a great deal of support from the average Black person, a deeper dive reveals that not all Black lives matter equally to Black people. To be specific, we find that while there is a great deal of support around Black women and formerly incarcerated Black people, upwards of two-thirds of Blacks are only willing to give lukewarm support, if any, to tackling the particular challenges posed to Black undocumented immigrants and Black LGBT people. This is an important line of research given that the life chances of undocumented immigrants as well as Black lesbian, gay, and transgender people are particularly precarious. Undocumented Black immigrants are over-represented among immigrants who are justice-involved (in large part due to their race), and are, thus, more likely to be deported on account of their status as unauthorized immigrants (Black Alliance for Just Immigration and NYU School of Law Immigrant Rights Clinic 2016; Smith 2017). The challenges that gender non-conforming Blacks face are well illustrated by the fact that the homicide rate for Black transgender people is one in 2,600, compared with one in 12,000 for Americans between the ages of 15 and 34 (Astor 2017). Our results highlight that inequities can also be produced within, and not just on, communities of color.

We aimed to delineate the mechanisms that push Black Americans toward or pull them away from participating in full-throated resistance against sexism, social and economic exclusion, xenophobia, and homophobia. Black respondents who believe that their life chances are inextricably linked to other Blacks are much more likely to want the status of marginalized groups to be improved, but this sentiment is not a panacea for Black solidarity. Our results consistently show that an orientation toward respectability politics dissuades Black Americans from believing that the challenges of Blacks who face double or triple forms of oppression ought to be seriously addressed. More specifically, we find that the notions outlined by the Moynihan Report still have effects on Blacks' prescriptions and proscriptions for Black uplift. What's more, we find that many Black Americans are not immune to hearing the call of the "law and order" dog whistle; those who are willing to allow police to practice racial profiling are also likely to police those they see as deviant and undeserving of their positive attention.

The uptick in attention and support of BLM and M4BL's organization represents potential for 21 st century Black politics to take a hard turn toward its radical roots (Dawson 2011). Organizations like the NAACP 
are even shifting their stance toward some traditionally marginalized groups, and still several dozen have provided public support and solidarity with BLM by joining under the umbrella of M4BL. But, these changes do not seem to have reached the average Black citizen, quite yet. Needless to say, "the success of other movements has been hampered by the inability of those movements to bring together the diverse opinions and differently situated individuals within that movement," ${ }^{8}$ and it appears that this new social movement is facing similar difficulties. This movement actually has little tolerance for those unwilling to support all Black lives, but it appears that intersectionality is not clearly expressed in the sentiments of average Black citizens.

A mainstreamed intersectional politics would be marked by normalized and deliberate attention to uplifting those who experience multiple axes of oppression. Our results do not provide evidence for that. Instead, they show the negative impact of respectability politics on the likelihood of broadly embracing those groups that find themselves struggling against a tone-deaf Republican majority on Capitol Hill and president whose blunt characterization of the Black community depicts African Americans (literally) in a war against themselves. ${ }^{9}$ Though our results suggest that there is a potential for social change as younger generational cohorts replace the "old guard" generation, this generational shift does not appear to be large enough to sustain major changes to Black politics' business as usual.

\section{NOTES}

1. Alicia Garza, Patrisse Cullors, and Opal Tometi founded the Black Lives Matter (BLM) Movement in 2013. There is a network of local BLM chapters-across the United States and internationally - and an online platform. The Movement for Black Lives (M4BL) can be likened to an umbrella organization, which consists of about four dozen local and national organizations such as the Black Youth Project 100, Mothers Against Police Brutality, the National Conference of Black Lawyers, and the BLM network as well as various supporting individuals. All supporters of the M4BL share a set of guiding principles and political, social, and economic demands in an effort toward an anti-racist society.

2. To our knowledge, the racial and ethnic politics literature has yet to provide a validated, quantitative measure of respectability politics. Our goal here is to leverage the theoretical apparatus provided to us by the extant literature as well as employ the questions that mimic components of the theory in the CMPS. Ultimately, we hope to spark a conversation about how to measure respectability politics, but do so from a position of intellectual humility.

3. Hajnal and Lee (2011) like Tasha Philpot (2017) show that the traditional "liberal-toconservative" scale cannot be neatly superimposed on Blacks' political attitudes, as "conservativism" means something quite different for Blacks in comparison to White Americans.

4. The predicted probabilities in Figure 5 are produced by simultaneously holding support for racial profiling and support for two parent families at their respective maximums while holding the remaining variables at their mean, and then comparing them to their respective minimums, while continuing to hold other variables at their mean. 
5. We also examined models that tested for the effects of "religiosity" (measured by the frequency of attendance to religious or spiritual services) on attitudes toward lesbian and gay as well as transgender Blacks. This variable was statistically significant and was in the negative direction, as one might expect, but these models were not otherwise different from the models we report in Table 1.

6. That is, the predicted probabilities in Figure 6 are produced by holding linked fate at its highest value, and then adjusting the two respectability politics measures from their lowest to highest values, while holding the remaining variables at their mean.

7. When reflecting upon the place of women in the Student Nonviolent Coordinating Committee, Stokely Carmichael is documented as having jested, "The position of women in SNCC is prone."

8. We thank one of the anonymous reviewers for this insight.

9. On the campaign trail, Donald Trump referred to Black neighborhoods as "war zones," depicted the routine chore of buying a loaf of bread as an activity likely to get Black urban dwellers shot, and described the uptick of gun violence in Chicago as a clear case of "carnage."

\section{REFERENCES}

Alexander, Michelle. 2010. The New Jim Crow: Mass Incarceration in the Age of Colorblindness. New York: The New Press.

Allen, Richard L., Michael C. Dawson, and Ronald E. Brown. 1989. "A Schema-Based Approach to Modeling an African-American Racial Belief System." The American Political Science Review 83 (2): 421-41.

Anderson, Monica. 2015. A Rising Share of the U.S. Black Population is Foreign Born. in Pew Research Center.

Astor, Maggie. 2017. Rights Groups Report Rise in Deadly Attacks on Transgender People. in New York Times. New York.

Aziz, Sahar. 2015. Irreconcilable Contradiction in "Respectability Politics". in Racism Review.

Barreto, Matt A., Lorrie Frasure-Yokley, Edward D. Vargas, and Janelle Wong. 2017. The Collaborative Multiracial Post-Election Survey (CMPS), 2016. Dataset: Los Angeles, CA.

Black Alliance for Just Immigration, and NYU School of Law Immigrant Rights Clinic. 2016. "The State of Black Immigrants." NYU School of Law: New York, NY. http:// stateofblackimmigrants.com.

Black Lives Matter Network. What we believe: We affirm that all black lives matter. https:// blacklivesmatter.com/about/what-we-believe/

Capers, K. Jurée, and Candis Watts Smith. 2015. "Straddling Identities: Identity Cross-Pressures on Black Immigrants' Policy Preferences." Politics, Groups, and Identities 4 (3): 393-424.

Carbado, Devon W., and Donald Weise. 2004. "The Civil Rights Identity of Bayard Rustin." Texas Law Review 82 (5): 1133-96.

Carter, Niambi M., and Efrén O. Pérez. 2016. "Race and Nation: How Racial Hierarchy Shapes National Attachments." Political Psychology 37 (4): 497-513.

Cohen, Cathy J. 1999. The Boundaries of Blackness: AIDS and the Breakdown of Black Politics. Chicago: University of Chicago Press.

Cohen, Cathy J. 2004. "Deviance as Resistance: A New Research Agenda for the Study of Black Politics.” Du Bois Review: Social Science Research on Race 1 (1): 27-45.

Cohen, Cathy J. 2010. Democracy Remixed: Black Youth and the Future of American Politics. Oxford: Oxford University Press.

Crenshaw, Kimberle. 1991. "Mapping the Margins: Intersectionality, Identity Politics, and Violence Against Women of Color." Stanford law Review 43 (6): 1241-99.

Dawson, Michael C. 1994. Behind the Mule: Race and Class in African-American Press. Princeton: Princeton University Press. 
Dawson, Michael C. 2001. Black Visions: The Root of Contemporary African-American Political Ideologies. Chicago: University of Chicago Press.

Dawson, Michael C. 2011. Not in Our Lifetimes: The Future of Black Politics. Chicago: University of Chicago Press.

Dawson, Michael C., and Megan Ming Francis. 2016. "Black Politics and the Neoliberal Racial Order." Public Culture 28 (178): 23-62.

Diamond, Jeff. 1998. "African-American Attitudes Towards United States Immigration Policy." International Migration Review 32 (2): 451-70.

DuVernay, Ava. 2016. 13th. Howard Barish, Ava DuVernay, and Spence Averick. Kandoo Films, Netflix.

Gay, Claudine, Jennifer Hochschild, and Ariel White. 2016. “"Americans' Belief in Linked Fate: Does the Measure Capture the Concept?" The Journal of Race, Ethnicity, and Politics 1 (1): 117-44.

Greer, Christina. 2013. Black Ethnics: Race, Immigration, and the Pursuit of the American Dream. New York: Oxford University Press.

Griffin, Horace. 2000. "Their own Received Them not: African American Lesbians and Gays in Black Churches." Theology \& Sexuality 2000 (12): 88-100.

Hajnal, Zoltan L., and Taeku Lee. 2011. Why Americans Don't Join the Party: Race, Immigration, and the Failure (of Political Parties) to Engage the Electorate. Princeton, NJ: Princeton University Press.

Harris, Fredrick C. 2014. "The Rise of Respectability Politics.” Dissent 61 (1): 33-37.

Harris-Perry, Melissa V. 2011. Sister Citizen: Shame, Stereotypes and Black Women in America. New Haven: Yale University Press.

Haynie, Kerry L., and Candis S. Watts. 2010. "Blacks and the Democratic Party: A Resilient Coalition.” In New Directions in American Political Parties, eds Jeffrey M. Stonecash. New York, NY: Taylor \& Francis, 93-109.

Higginbotham, Evelyn Brooks. 1992. “African-American Women's History and the Metalanguage of Race." Signs: Journal of Women in Culture and Society 17 (2): 251-74.

Higginbotham, Evelyn Brooks. 1993. Righteous Discontent: The Women's Movement in the Black Baptist Church, 1880-1920. Cambridge, MA: Harvard University Press.

Horowitz, Juliana Menasce, and Gretchen Livingston. 2016. "How Americans view the Black Lives Matter movement." Pew Research Center: Washington, DC. http:// www.pewresearch.org/fact-tank/2016/07/08/how-americans-view-the-black-lives-mattermovement/

Houston, Shannon M. 2015. "Respectability will not save us: Black Lives Matter is right to reject the 'dignity and decorum" mandate handed down to us from slavery.' in Salon.

Hutson, Wendell. 2013. "Despite Support From Obama and Jackson, Blacks Still Split on Gay Marriage." in DNAinfo.

Ioffe, Julia. 2014. "No One Treats American Americans Worse than They Treat Each Other." in New Republic.

Jordan-Zachery, Julia S. 2007. "Am I a Black Woman or a Woman Who is Black? A Few Thoughts on the Meaning of Intersectionality." Politics \& Gender 3 (2): 254-63.

Kennedy, Randall. 2015. "Lifting as we climb." Harper's Magazine 26.

Kim, Claire Jean. 2000. Bitter Fruit: The Politics of Black-Korean Conflict in New York City. New Haven: Yale University Press.

King, Martin Luther Jr.. 1969. “A Testament of Hope.” Pp. 174, 94, 231-36 in Playboy Magazine.

Kluegel, James R. 1990. “Trends in Whites' Explanations of the Black-White Gap in Socioeconomic Status, 1977-1989.” American Sociological Review 55 (4): 512-25. 
Lerman, Amy E., and Vesla M. Weaver. 2014. Arresting Citizenship: The Democratic Consequences of American Crime Control. Chicago, IL: University of Chicago Press.

Lopez Bunyasi, Tehama and Candis Watts Smith. 2018. "Get in Formation: Black Women's Participation in the Women's March on Washington as an Act of Pragmatic Utopianism." The Black Scholar 48 (3): 4-16.

Masuoka, Natalie, and Jane Junn. 2013. The Politics of Belonging: Race, Public Opinion, and Immigration. Chicago, IL: University of Chicago Press.

McClain, Dani. 2017. “The Rev. William Barber Is Bringing MLK's Poor People's Campaign Back to Life." in The Nation.

McClain, Paula, Jessica D. Johnson Carew, Eugene Walton Jr., and Candis S. Watts. 2009. "Group Membership, Group Identity, and Group Consciousness: Measures of Racial Identity in American Politics?” Annual Review of Political Science 12: 471-84.

McQuirter, Keith. 2016. "Milwaukee 53206." Transform Films Inc.

Movement for Black Lives. "Platform." https://policy.m4bl.org/platform/.

Moynihan, Patrick. 1965. The Negro Family: The Case for National Action. Washington, DC: Office of Policy Planning and Research.

NAACP. 2015. BlackLivesMatter, Criminalization, and Disaster Justice. NAACP. https:// www.naacp.org/latest/blacklivesmatter-mass-incarceration-and-disaster-justice/

Obasogie, Osagie K, and Zachary Newman. 2016. "Black Lives Matter and Respectability Politics in Local News Accounts of Officer-Involved Civilian Deaths: An Early Empirical Assessment." Wisconsin Law Review 541 (3): 541-574.

Olsen, Marvin. 1970. "Social and Political Participation of Blacks." American Sociological Review 35 (4): 682-97.

Pager, Devah. 2007. Marked: Race, Crime, and Finding Work in an Era of Mass Incarceration. Chicago: University of Chicago Press.

Pew Research Center. 2014. Religious Landscape Study. Pew Research Center: Washington, DC. http://www.pewforum.org/religious-landscape-study

Philpot, Tasha S. 2017. Conservative but Not Republican. New York: Cambridge University Press.

Price, Melanye T. 2009. Dreaming Blackness: Black Nationalism and African American Public Opinion. New York: New York University Press.

Price, Melanye T. 2016. The Race Whisperer: Barack Obama and the Political Uses of Race. New York, NY: NYU Press.

Pugh, Aleo. 2017. "The Misappropriation of MLK: Respectability Politics and Black Struggle.” in BDG.

Reynolds, Barbara. 2015. "I was a civil rights activist in the 1960s. But it's hard for me to get behind Black Lives Matter.": Washington Post.

Rickford, Russell. 2016. "Black Lives Matter Toward a Modern Practice of Mass Struggle." New Labor Forum 25 (1): 34-42.

Rivas, Jorge. 2016. "Black Lives Matter is Joining the Fight Against Deportations—it could be a game changer." in Fusion.

Rogers, Reuel R. 2006. Afro-Caribbean Immigrants and the Politics of Incorporation: Ethnicity, Exception, or Exit. New York: Cambridge University Press.

Sanchez, Gabriel R., and Edward D Vargas. 2016. "Taking A Closer Look at Group Identity: The Link Between Theory and Measurement of Group Consciousness and Linked Fate." Political Research Quarterly 69 (1): 160-74.

Schneider, Anne, and Helen Ingram. 1993. "Social Construction of Target Populations: Implications for Politics and Policy." American Political Science Review 87 (2): 334-47.

Sevecke, Jessica R, Katrina N Rhymer, Elbert P Almazan, and Susan Jacob. 2015. "Effects of Interaction Experiences and Undergraduate Coursework on Attitudes Toward gay and Lesbian Issues." Journal of Homosexuality 62 (6): 821-40. 
Shingles, Richard D. 1981. "Black Consciousness and Political Participation: The Missing Link.” The American Political Science Review 75 (1): 76-91.

Simien, Evelyn M. 2005. "Race, Gender, and Linked Fate." Journal of Black Studies 35 (5): 529-50.

Simien, Evelyn M, and Rosalee A Clawson. 2004. "The Intersection of Race and Gender: An Examination of Black Feminist Consciousness, Race Consciousness, and Policy Attitudes"." Social Science Quarterly 85 (3): 793-810.

Smith, Candis Watts. 2014. Black Mosaic: The Politics of Black Pan-Ethnicity. New York, NY: New York University Press.

Smith, Candis Watts. 2017. "Black Immigrants in the US face big challenges." in Monkey Cage. Washington Post.

Smooth, Wendy. 2006. "Intersectionality in Electoral Politics: a Mess Worth Making." Politics \& Gender 2 (3): 400-14.

Spence, Lester K. 2011. Stare in the Darkness: The Limits of Hip-Hop and Black Politics. Minneapolis: University of Minnesota Press.

Spence, Lester K. 2012. “The Neoliberal Turn in Black Politics.” Souls 14 (3-4): 139-59.

Stanford, Anthony. 2013. Homophobia in the Black Church: How Faith, Politics, and Fear Divide the Black Community. Santa Barbara, CA: Praeger.

Tajfel, Henri, and John C Turner. 1986. The Social Identity Theory of Intergroup Behavior. In Psychology of Intergroup Relations, eds Stephen Worchel and William G. Austin. Chicago: Nelson-Hall Publishers, 7-24.

Tate, Katherine. 2010. What's Going On? Political Incorporation and the Transformation of Black Public Opinion. Washington, DC: Georgetown University Press.

Taylor, Keeanga-Yamahtta. 2016. From \#BlackLivesMatter to Black Liberation. Chicago, IL: Haymarket Books.

Taylor, Keeanga-Yamahtta, ed. 2017. How We Get Free: Black Feminism and the Combahee River Collective. Chicago: Haymarket Books.

Verba, Sidney, and Norman Nie. 1972. Participation in American: Political Democracy and Social Equality. New York: Harper and Row.

Waddington, P.A.J. 1999. Policing Citizens: Police, Power and the State. New York: Routledge.

Ward, Elijah G. 2005. "Homophobia, Hypermasculinity and the US Black Church." Culture, Health 6 Sexuality 7 (5): 493-504. 


\section{APPENDIX}

\section{QUESTION WORDING OF INDEPENDENT VARIABLES AND DISTRIBUTION OF RESPONSES AMONG BLACK RESPONDENTS}

\section{Linked Fate}

- Do you think what happens generally to Black people in this country will have something to do with what happens in your life?

- If yes, Will it affect you: A lot, Some, or Not Very Much?

\begin{tabular}{lc}
\hline A lot of linked fate & $24.7 \%$ \\
Some linked fate & $37.7 \%$ \\
Not very much linked fate & $4.8 \%$ \\
No linked fate & $32.8 \%$ \\
\hline
\end{tabular}

- Some people feel positively about the link they have with their racial or ethnic group members, while others feel negatively about the idea that their lives may be influenced by how well the larger group is doing. Which comes closer to your feelings?

- I feel positively about this link with my racial or ethnic group; I feel negatively about this link with my racial or ethnic group; Neither positive or negative.

\section{Respectability Politics}

- Of the following statements, which do you agree with more? Blacks should focus on making sure families have two parents; Blacks should focus on making sure all families are supported no matter their make-up.

- Please indicate if you agree or disagree with each statement: Racial profiling is sometimes necessary as a law enforcement tool "Racial profiling" refers to targeting individuals from certain groups in the belief that they are more likely to commit crimes.): Strongly agree; Somewhat agree; Somewhat disagree; Strongly disagree. 


\section{Individualist Explanation of Inequality}

- According to census statistics, White Americans have higher income, education attainment and homeownership rates than Black Americans. Of the following factors, please indicate whether or not each one is important or unimportant in explaining BlackWhite disparities?: Racial discrimination against Blacks; Lower quality of schools in Black communities; Lack of effort by Blacks; Family instability in the Black community. - Responses: Very important; Somewhat important; Not very important; Not important at all - Scale Reliability Coefficient: .74

- Negative scores correspond to greater reliance on "structural" explanations of inequality (e.g. racial discrimination, lower quality of schools). Positive scores correspond to greater reliance on "individual" attributions of inequality (e.g. lack of effort, family instability)

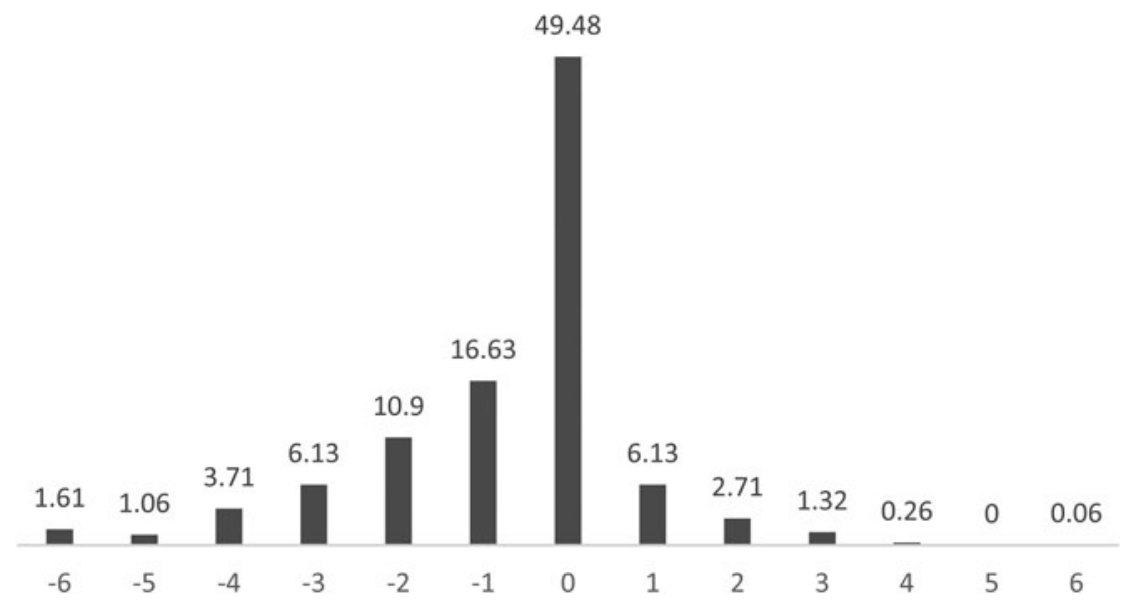


DISTRIBUTION OF BLACK AMERICANS' RESPONSES

\begin{tabular}{|c|c|c|c|c|c|c|c|c|}
\hline & \multicolumn{2}{|c|}{ Linked Fate (\%) } & \multicolumn{2}{|c|}{$\begin{array}{l}\text { Positive Linked } \\
\text { Fate }(\%)\end{array}$} & \multicolumn{2}{|c|}{ Family Structure (\%) } & \multicolumn{2}{|c|}{$\begin{array}{c}\text { Racial Profiling } \\
(\%)\end{array}$} \\
\hline & $\begin{array}{l}\text { A lot/Some/ } \\
\text { Not very much }\end{array}$ & $\begin{array}{l}\text { No Linked } \\
\text { Fate }\end{array}$ & Positive & $\begin{array}{c}\text { Not } \\
\text { Positive }\end{array}$ & $\begin{array}{c}\text { Support } \\
\text { All Families }\end{array}$ & $\begin{array}{c}\text { Support } \\
\text { Two Parents }\end{array}$ & Disagree & Agree \\
\hline \multicolumn{9}{|l|}{ Gender } \\
\hline Black women & 66.6 & 33.4 & 43.8 & 56.2 & 86.1 & 13.9 & 74.6 & 25.4 \\
\hline Black men & 68.6 & 31.4 & 47.9 & 52.1 & 76.5 & 23.5 & 73.5 & 26.5 \\
\hline \multicolumn{9}{|l|}{ Educational Attainment } \\
\hline College degree and higher & 72.5 & 27.5 & 51.6 & 48.4 & 84.5 & 15.5 & 78.8 & 21.2 \\
\hline Less than college degree & 64.8 & 35.2 & 42.2 & 57.8 & 82.5 & 17.5 & 72.1 & 27.9 \\
\hline \multicolumn{9}{|l|}{ Partisanship } \\
\hline Democrat & 62.5 & 37.5 & 48.8 & 51.2 & 86 & 14 & 75.4 & 24.6 \\
\hline Independent & 63.4 & 36.6 & 36.6 & 63.4 & 79.9 & 20.1 & 75.6 & 24.4 \\
\hline Republican & 56.7 & 43.3 & 41.1 & 58.9 & 59 & 41 & 47.5 & 52.5 \\
\hline \multicolumn{9}{|l|}{ Political Ideology } \\
\hline Liberal & 74 & 26 & 55.1 & 44.9 & 84.9 & 15.1 & 74.6 & 25.4 \\
\hline Moderate & 68.3 & 31.7 & 42.4 & 57.6 & 83.9 & 16.1 & 75.2 & 24.8 \\
\hline Conservative & 59.3 & 40.7 & 40.5 & 59.5 & 79.8 & 20.2 & 70.1 & 29.9 \\
\hline
\end{tabular}

